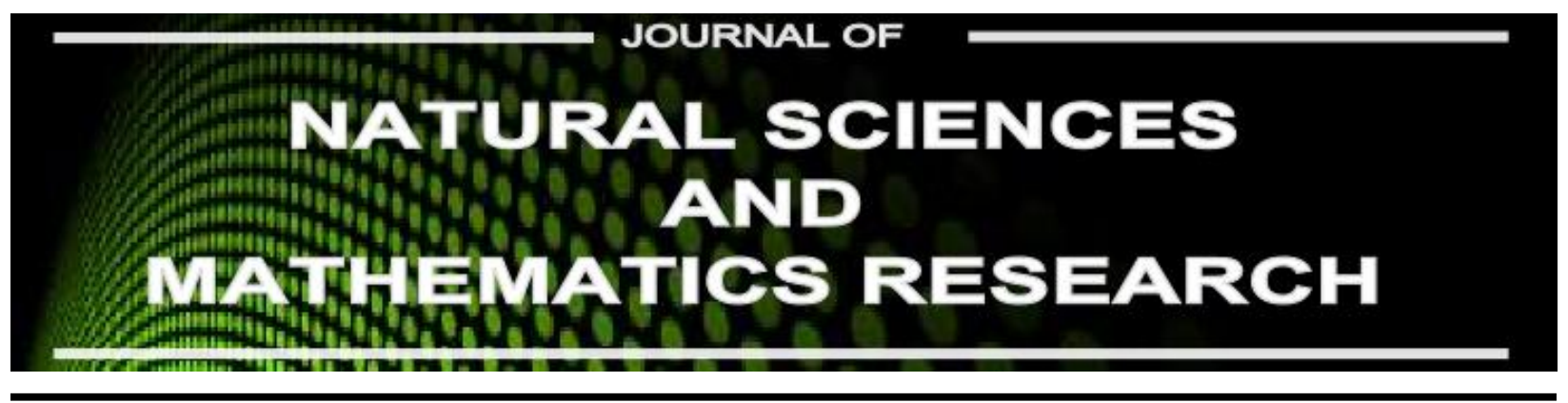

Available online at http://journal.walisongo.ac.id/index.php/jnsmr

\title{
Richness of Butterflies Species at Three Habitat Type in Karimunjawa Island Central Java
}

Wisnu Bayu Murti ${ }^{1}$, Nugroho Edi Kartijono ${ }^{2}$, and Margareta Rahayuningsih ${ }^{3}$

${ }^{1}$ Department of Biology, Faculty of Natural Science and Mathematics, Semarang State University, Central Java, Indonesia

\begin{abstract}
s
Corresponding author: The purpose of this research was to determine the species richness of butterflies bayumurtiw@gmail.com Recived: 12 November 2016, Revised : 18 December 2016 Accepted: 30 December 2016. on three type habitats in Karimunjawa Island. The research was conducted in May-October 2016. The research location on the island of Karimunjawa in three habitat types, edge of lowland tropical forest, paddy fields and settlements. Sampling was conducted four times of observation on each habitat type and Point Count Method. Identification species of butterflies use a guidebook Serangga Taman Nasional Gunung Halimun Jawa Bagian Barat and analyzed by uses Margalef Index. The results showed total 49 species of butterflies from 1402 individual (5 Family) was found in three types of habitat. Butterfly species richness highest in a edge habitat of lowland tropical forest (5.9), settlements (5.2), and paddy fields (4.6). (C)2016 JNSMR UIN Walisongo. All rights reserved.
\end{abstract}

Keywords: Species Richness; Butterflies; Karimunjawa Island.

\section{Introduction}

National Park of Karimunjawa is conservation areas which has unique and complete ecosystem. Many representation of ecosystem type at national park of Karimunjawa is save potential biological variety and is not completely data yet. Representation of ecosystem in waterworks area that is coral ecosystem, seaweed field, and mangrove forest. Mean while, in land area of Karimunjawa National Park consist of beach forest or forest of low land tropical rain, where in this area is habitat of various flora and fauna included the butterfly [1].

Based on preface survey that is done by LIPI at 2001, Natioanl Park of Karimunjawa have 23 kinds of butterfly. Among them are 2 kinds of endemic butterfly of Karimunjawa that is Idea leuconoe karimondjawae and Euploea crameri karimondjawaensis. Those research only done in several block of low land tropical rain forest and its not include paddy field or settlement area [2].

Butterfly is part of biological variety that should be kept the preservation from extinction 
or descent kinds variety. The effort is need because butterfly have important values such as: ecology value, endemic value, conservation value, education value, culture value, aesthetic value, and economic value [3]. Doing a butterfly conservation effort in Karimunjawa island is needed based data, one of them is the richness of butterfly kinds in Karimunjawa Island. In context of development and planning conservation is need scientific data [4]. Because of that it will done a research about the richness of butterfly kinds that consist of three habitat type in Karimunjawa Island. This research is important considering there is no complete data and information about richness of butterfly kinds especially outside the block of ow land tropical rain forest in Karimunjawa Island.

The purpose of this research is to know the richness of butterfly kinds in three habitat type at Karimunjawa Island Central Java, especially in the edge of low land tropical rain forest, paddy field area or settlement area.

\section{Experiments Procedure}

The research is done in Karimunjawa Isalnd Central Java, consist of three habitat i.e. edge of ow land tropical rain forest (Legon Lele), paddy field area (Dusun Cikmas), or settlement (Dusun Kemloko, Nyamplungan, dan Alang-alang). Collecting data is done on August - September 2016. Observation is don or e used count point method or known as method of Point Count [5]. In this method observer is stand up in a location that decided during 40 minutes and recorded and counted the amount of kinds and amount of butterfly kind individuate. Observation is done in point count which is placed on the line that decided before. Every point count have radius limit of $20 \mathrm{~m}$ from the observer standing position. The distance between point count is minimum 100 $\mathrm{m}$, it is intended to minimize the possibility of double counting [4].

Observation time is done stated from 6.3011.00 WIB. It is done, when butterfly activity is high enough and the sun is illuminate enough or to dry their wings. In taking sample of each habitat is done 4 time repetition, the purpose of this repetition is in order that new species of butterfly in imago stadium can be observed, it because generally butterfly have live circle more over 27-31 days. The butterfly is not identified yet, is taken their detail picture used digital camera and then input it to envelope or papilot for preserved and identified more detailed. Butterfly identification is done in laboratory of Semarang State University used pilot book by Kahono et al 2003. The data will be analyzed used Indeks Margalef $\left(D_{\mathrm{mg}}\right)$.

Richness value of butterfly species can be determined used indeks Margalef"s used abbreviation [6].

where,

$$
\mathrm{D}_{\mathrm{mg}}=(\mathrm{S}-1) / \ln \mathrm{N}
$$

$\mathrm{S}=$ Number of butterfly species

$\mathrm{N}=$ Number of individual from entire species

\section{Results and Discussion}

Research result in Karimunjawa Island from three composition habitat, the research species is as many as 49 species consist of 1402 individual which grouped in 5 family (Table 1). Those family are Papilionidae, Pieridae, Lycaenidae, Nymphalidae, and Hesperidae. The research is successful find one endemic butterfly species in Karimunjawa Island that is Idea lueconoe karimondjawae which the existence is rare found. Based on research result of richness species in entire habitat based on Margalef index i.e 6.6 (Table 1).

Table 1. Number of individual, number of butterfly species, and Margalef index on three habitat type in Karimunjawa Island

\begin{tabular}{lllll}
\hline & PM & PS & TH & Total \\
\hline $\mathrm{S}$ & 36 & 27 & 35 & 49 \\
\hline $\mathrm{F}$ & 5 & 5 & 5 & 5 \\
\hline $\mathrm{N}$ & 805 & 280 & 317 & 1402 \\
\hline Dmg & 5.2 & 4.6 & 5.9 & 6.6 \\
\hline
\end{tabular}

Note: PM : settlement

PS : paddy field area

$\mathrm{TH}$ : edge of low land tropical rain forest

F : Family 
Distribution of butterfly species in great quantity as long as research is Zizina otis with quantity 211 individual which is found in entire observed habitat. The big quantity of this species butterfly is because of the body size and small wings so thy can fly high, this butterfly also usually found in grouped with 5-28 individual. According Peggie [7] this butterfly is likes open area and perch or looking the food in the grassland, it is appropriate with observation area that part of it is open area and have under layer vegetasi in the form of grass and herb.

Observation result on settlement area shows that quantity of individual and highest butterfly species, that is 805 individual and 37 species. The higher number is influenced by existence of plan or enough food, then opened area give enough light intensity for butterfly to fulfill their daily live, so it caused this habitat is very liked by butterfly. The research result is also supported by Dewenter \& Tscharntke that variety of butterfly species is more increase with the variety of plan and it decrease with the closed vegetasi [8]. The data is appropriate with observation result that is done in paddy field area. Individual quantity and butterfly species on this area is lowest from the three observed habitat that is 280 individual and 28 species. It is influenced by less existence and less variety of mother plan or food for butterfly in the location.

On the edge area of low land tropical rain forest is gain individual quantity and quantity of second higher species, that is 317 individual and 35 species. It is because of some observation point which have vegetasi cover. Beside that, the condition of speedy wind on east side of Karimunjawa Island caused big part of butterfly take shelter in forest or probability migrated to the west side of Karimunjawa Island, where the big part of it is settlement area.

The research in three habitat type show that butterfly species from Nymphalidae family is the greatest number is $45 \%$ with quantity 22 species. Hesperidae family is family with smallest proportion is $8 \%$ with quantity 4 species (see in the Figure 1). Based on many research report of Hesperidae family is family which have species composition and greater number of individual proportion in various research location, such as Banyuwindu village, Limbangan city, Kendal regency [5], kehati park of Semarang State University [9], Wana Wisata Alas Bromo [10], Nymphalidae family is biggest family of Pepilionidae super family. The high of species composition or individual proportion of Nymphalidae family butterfly is influence of polyfag character (they have more than one kind of food) that had by Nymphalidae family so it make possible for Nymphalidae family to fulfill their need of mother plant even though the main mother plant is not exist [9].

Family with smallest species proportion in the research is Hesperidae, although the quantity of mother plant species and woof plant is not the smallest of other family, however the smallest proportion of this species is influenced by Hesperidae character which more like place with a little moist and shade [11]. Hasperidea have krepuskular character (they are active toward night or when blurred of light) [12]. Field observation time is done in the morning time until day light, on that time the light intensity is high so this condition caused meeting with Hesperidae family is small or little.

Richness index of Margalef $\left(D_{m g}\right)$ species is very influence by number quantity of individual which meet in certain area. Based on analysis used Margalef index on settlement area is gain $D_{\text {mg }}$ value (5.2). Data analysis result show that although quantity of butterfly species in settlement habitat is the greatest number (377 species, 805 individual), however their $D_{m g}$ value is not the highest. The highest $D_{m g}$ value is on the edge forest habitat of low land tropical rain (5.9) and value of $D_{m g}$ index is lowest is in paddy area (4.6).

Species richness of butterfly at edge forest tropical of low land is bigger than if it compared with the settlement because the lowest domination of that habitat. At settlement habitat also found domination of 2 butterfly species that is Junonia atlites (93 individual, $33.2 \%)$ and Zizina otis $(62,24 ., 3 \%)$. It is caused by the higher domination at the species which is influenced by overflow of the mother plant for butterfly, so quantity of imago individual 
become in great quantities and meeting frequency is more often [11].

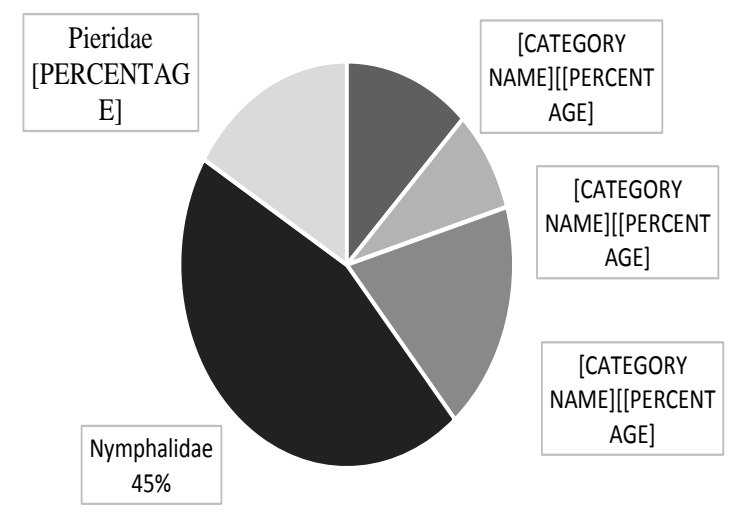

Figure 1. Proportion of Butterfly species on three habitat type at Karimunjawa Island.

\section{Conclusion}

Research result show that total quantity as many as 49 butterfly species from 1402 individual is grouped in 5 family that found in three habitat type. Richness of butterfly species in Indeks Margalef in a row is habitat of forest edge of low land tropic $(5,9)$, habitat of settlement area $(5,2)$, and habitat of paddy land $(4,6)$.

\section{Acknowledgment}

The authors wish to thank Department of Biology, UNNES for supporting this work.

\section{References}

[1] BTBKJ, Selamat Datang Di Taman Nasional Karimunjawa. Semarang: Balai Taman Nasional Karimunjawa, 2010.

[2] P. Prihatiningsih, Laporan Identifikasi dan Inventarisasi Kupu-kupu. Semarang: Balai Taman Nasional Karimunjawa, 2009.

[3] R. Oqtafiana, P. Bambang dan R. Margareta, Keanekaragaman Jenis
Kupu-Kupu Superfamili Papilionoidae di Banyuwindu, Limbangan Kendal. Biosantifika 5(1), pp. 59-64, 2013.

[4] M. Rahayuningsih dan P. Bambang, Bird community in Taman Kehati Universitas Negeri Semarang, Indonesia. International Jurnal of Ecology and Development. 31(1), 2016.

[5] M. Rahayuningsih, O. Ratna dan P. Bambang, Keanekaragaman Jenis KupuKupu Superfamili Papilionoidae di Dukuh Banyuwindu Desa Limbangan Kecamatan Limbangan Kabupaten Kendal. Jurnal MIPA. 35(1), pp.12-20, 2012.

[6] A.E. Magurran Ecological Diversity and Its Measurement. New Jersey: Pricenton University Press, 1987.

[7] D. Peggie, Mengenal Kupu-kupu. Jakarta : Pandu Aksara Publishing, 2014.

[8] S. Koneri dan Saroyo, Distribusi dan Keanekaragaman Kupu-Kupu (Lepidoptera) di Gunung Manado Tua, Kawasan Taman Nasional Laut Bunaken, Sulawesi Utara. Jurnal Bumi Lestari. 12(2), pp. 357-365, 2012. 
[9] B. Priyono dan A. Muhammad, Keanekaragaman Jenis Kupu-Kupu di Taman Kehati Unnes. Biosaintifika. 5(2), pp. 77-81, 2013.

[10] D.F. Lestari DF, D.A.P. Rizma, R. Muhammad dan D.P. Atika, Keanekaragaman Kupu-kupu (Insekta: Lepidoptera) di Wana Wisata Alas Bromo, BKPH Lawu Utara, Karanganyar, Jawa Tengah. Dalam: Prosiding Seminar Nasional Masyarakat Biodiversitas Indonesia. Jurusan Biologi FMIPA Universitas Sebelas Maret Surakarta. Pp. 1284-1288, 2015.
[11] T.H. Sulistyani, Keanekaragaman Jenis Kupu-Kupu (Lepidoptera: Rhopalocera) di Kawasan Cagar Alam Ulolanang Kecubung Kabupaten Batang (Skripsi). Semarang: Universitas Negeri Semarang, 2013.

[12] S. Kahono S, A. Mohammad, A. Pudji, Erniwati, U. Rosichon, E.P. Liliek, A.N. Woro dan S. Awit, Serangga Taman Nasional Gunung Halimun Jawa Barat. Bogor : BCP-JIKA, 2003. 